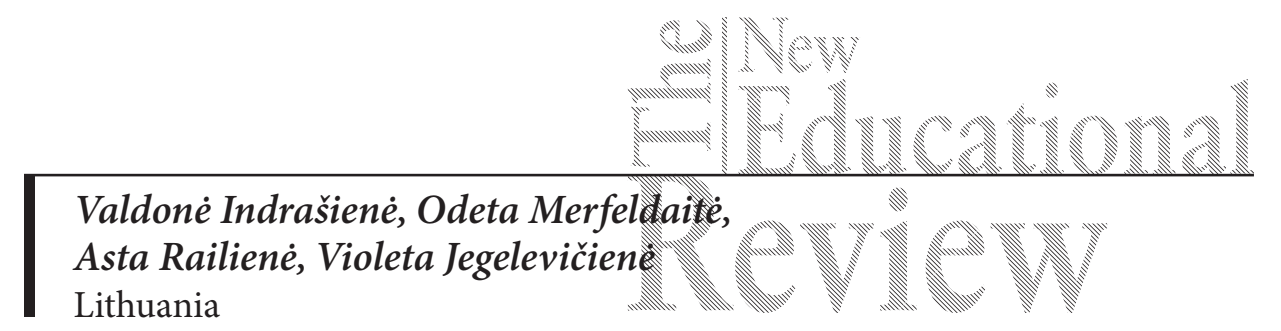

\title{
Experience in Using Information Communication Technology during Lessons in General Education Schools
}

DOI: $10.15804 /$ tner.2015.40.2.08

\begin{abstract}
Contemporary school is inconceivable without the integrated interactive learning tools and information communication technologies (hereinafter referred to as ICT) in the education process. However, according to research, ICT integration in the learning process is insufficient. The aim of this research is to analyse the experience of pedagogues in using ICT during lessons.
\end{abstract}

Keywords: information communication technologies, education process, pedagogues

\section{Introduction}

The use of ICT in education is an important element in the European Commission's strategy ensuring effective European education systems and competitiveness of the European economy (Key Data on Learning and Innovation through ICT at School in Europe, 2011). European Union (EU) and UNESCO institutions place great importance on integration of ICT in the education process and on the teacher ICT competences, since successful integration enhances the learning process, makes it more attractive, promotes cooperation, authentic learning, motivation of pupils and teachers, and helps to effectively solve problems in the contemporary ICT-driven world (The ICT Impact Report, A Review of Studies of ICT Impact on Schools in Europe, 2006). According to the strategic EU documents, promotion of teachers' creativity and innovation through ICT is one priority area, therefore teachers' ICT qualification should be focused (Teaching and Learning for an ICT 
Revolutionised Society, 2010, Key Data on Learning and Innovation through ICT at School in Europe, 2011).

According to research, in other countries integration of ICT in the learning process is also insufficient; most often schools fail to develop the vision of the effective integration of ICT in the education process (Kuskaya-Mumcu, KoçakUsluel, 2013) and are not able to reach their full potential (Fredriksson, Gajek, Jedeskog, 2009). The main causes are: absence of a common policy in the EU Member States, and lack of trust, competence and resources in ICT integration (Bingimlas, 2009).

Research revealed that changes related to the integration of ICT in education are slow, whereas the impact of ICT on teaching highly depends on ICT usage in the education process (The ICT Impact Report. A Review of Studies of ICT Impact on Schools in Europe, 2006). Basic ICT skills are insufficient to teach pupils (E-Teacher 2.0 Empowering Teacher's ICT-Pedagogical Competencies. 2010). Effective ICT integration requires much more than the technical knowledge of how to use the devices (UNESCO ICT Competency Framework for Teachers, 2011). This requires fundamental changes in the teaching/learning framework, teaching paradigms/ methods and consolidation of new methodologies; thus, teachers should have the opportunity to engage in training, to deepen their understanding and mastery of ICT as a tool for innovating teaching approaches'.

According to the data of the OECD Teaching and Learning International Survey (TALIS), the major need for further improvements in Lithuania is related to the teaching practice and understanding/adopting relevant methods. Whereas globally the major professional development needs in the rapidly changing areas are due to globalisation, e.g. teachers' ability to use/apply ICT in the education process (Information Technologies in the $21^{\text {st }}$ Century Schools, 2010, Professional Development of Lithuanian Teachers, 2010).

\section{Research Problem}

The research revealed that Lithuanian students' level of computer/information literacy is moderate. Although students do have basic skills, they are less successful in accomplishing creative and independent tasks (Fraillon, Ainley, etc., 2013); besides, students are more likely to use computer at home rather than at school, and the use of the virtual learning environment (especially outside of school) is

\footnotetext{
${ }^{1}$ A Framework to Support Teachers' CPD in the use of ICTs. Public Progress Report, 2007; Punie, Zinnbauer, Cabrera, 2006; Key Data on Learning and Innovation through ICT at School in Europe 2011.
} 
still not common in many countries (Survey of Schools: ICT in Education. Benchmarking Access, Use and Attitudes to Technology in Europe's Schools, 2013). The main factor determining the level of students' ICT skills is the teacher capable of organising and managing the ICT-based teaching/learning process in a creative manner. However, the survey (Survey of Schools: Information Communication Technology (ICT) in Education. Information about Lithuania) revealed that teachers use ICT in teaching/learning on rare occasions. Development of ICT competency and possibilities for further development could be specified only after an in-depth situation analysis and the analysis of the current experience in using ICT during lessons in Lithuanian general education institutions.

\section{Research Methodology}

\section{Research General Background}

The research was based on the methodological (or normative) paradigm of quantitative research for social sciences interpreting social reality as a positivist attitude. In view of this, what is focused is the relationship between theory and empirical research. Quality is usually determined by quantitative indicators. According to global science, quantitative analysis is a typical procedure required for in-depth research (Bitinas, 2006).

\section{Research Sample}

The research analysis includes: the impact of ICT on teaching/learning (Punie, Zinnbauer, Cabrera, 2006; Ross \& Lowther, 2009); connection between the use of ICT tools and teaching methods (Dagienè, Jasutienè, 2007; Means, 2010, Kriliuvienė, 2010, Pečiuliauskienè, 2010, Prell, 2011, Brazdeikis, Masaitis, 2011, Gudoniene, 2011), and application of the ICT-based educational environment (Brazdeikis, 2010; Jucevičienè, 2013; Žadeikaitè, Gulbinas, 2014). Teacher competence issues are considered by the researchers as one of the key ICT usage factors (Anderesen, Weert, 2002; Gedvilienè etc., 2010, Jucevičienė, Brazdeikis, 2012), as well as problems related to ICT integration into subject teaching (Bingimlas, 2009; Navickaitė, 2010; Orintienè, Lazauskienė, 2010; Tamošiūnas, 2010; Paulionytė et.al, 2010; Indrašienė et al., 2010, Lukšènienė, Žygaitienė, Pošiūnaitė, 2014).

\section{Instrument and Procedures}

The research instrument is a questionnaire survey for pedagogues. In order to determine the internal consistency (reliability) of questionnaire scales, Cronbach's 
alpha coefficient was applied (based on the correlations between variables and evaluating on whether the sample size is adequate (Pukenas, 2011): questionnaire block on pedagogues' competence in integrating ICT into subject teaching - Cronbach's Alfa ( $\alpha=0.764)$; questionnaire block on the use of ICT during the teaching process - Cronbach's Alfa ( $\alpha=0.806)$. According to the obtained results, the indicators selected in the questionnaire define the analysed features; their analysis will determine pedagogues' attitudes toward the implementation of ICT tools in the education process and their experience in applying these tools in practice

The research involved 605 pedagogues working in pre-middle school $(n=277)$ grades $7-8$ and middle school $(n=328)$ grades $10-11$ of the four largest Lithuanian cities. The sampling was based on a cluster sampling method due to the wide spread of pedagogues' population. In view of this, pedagogues were selected after a random selection of pre-middle schools/middle schools. This is a representative sampling assuming a 95 percent confidence level and a margin of error of 5 percentage points. The research analysis was made using SPSS 18 (Statistical Package for Social Sciences) software package. The methods of dispersive and cross-correlation analysis and multiple regression were applied to process the obtained data (Vaitkevičius et al., 2006; Longitudinal data analysis, 2009).

\section{Research Results}

Profile of the respondents. The study comprised science teachers $(n=605)$ : teachers of mathematics (25.2\%), biology (24.9\%), physics (25.1\%) and chemistry $(24.8 \%)$. By pedagogical qualification the breakdown of the teaching staff was as follows: teachers $(24.6 \%)$, senior teachers $(24.5 \%)$, teachers-supervisors $(25 \%)$ and teachers-experts $(26 \%)$.

The research included qualified and competent pedagogues: $58.7 \%$ of the respondents reported 10 and more years of pedagogical experience, $27.1 \%-15-25$ years, and $12.2 \%$ reported having more than 25 years of experience.

The IT (information technology) experience of pedagogues in the learning process is determined by multiple interrelated or interdependent variables. In view of this, correlation analysis was applied, as well as calculation of Spearman's correlation coefficient (rs). Correlation analysis included the pedagogues' knowledge, abilities, attitude changes and ICT tools most frequently used in subject teaching. Table 1 provides only statistically significant outcomes.

Pursuant to the data analysis, the better pedagogues evaluate their knowledge on basic provisions for ICT integration in the subject teaching, the more frequently 


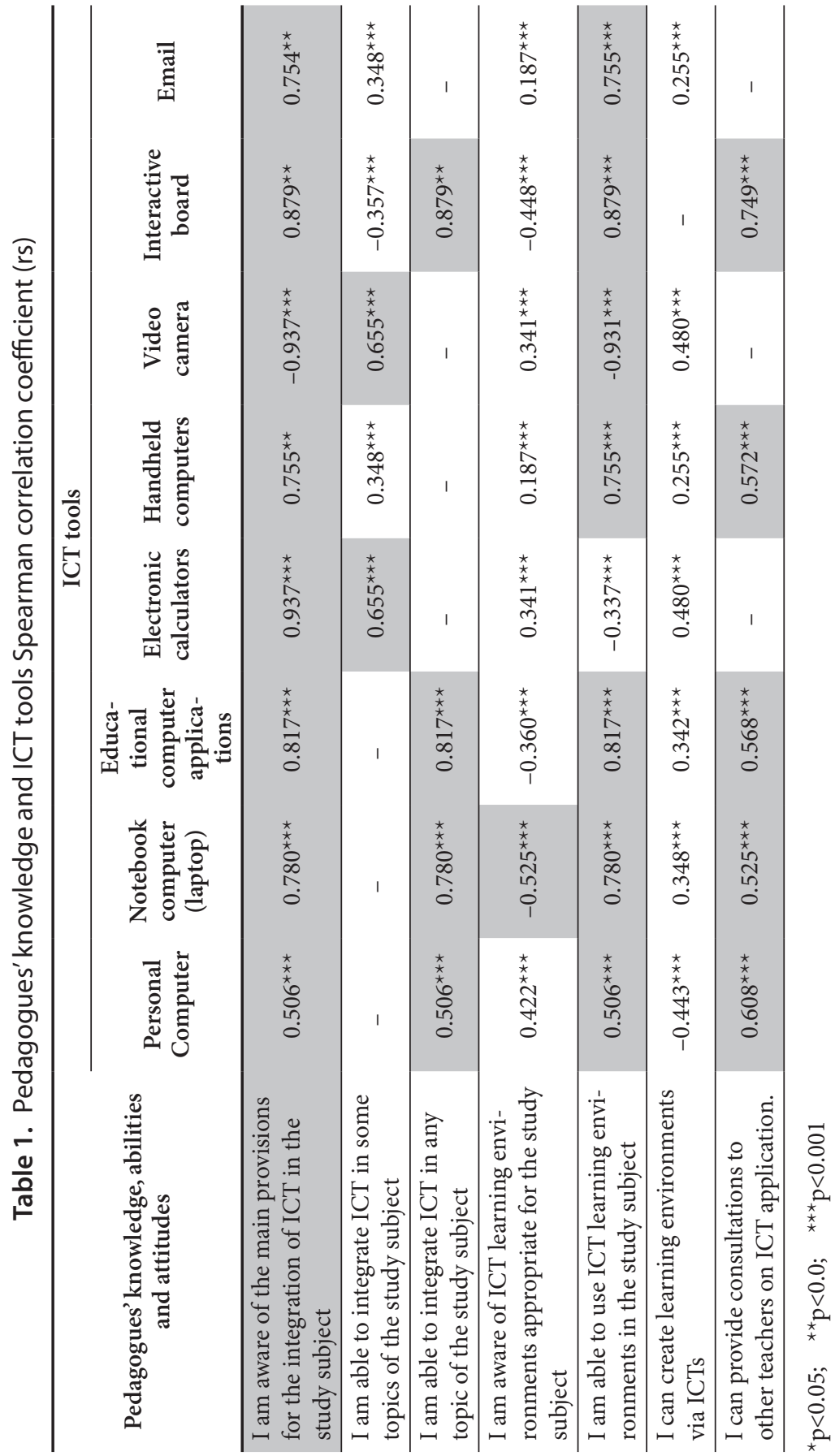


they use personal computer ( $\mathrm{rs}=0.506, \mathrm{p}<0.0001)$, notebook $(\mathrm{rs}=0.780, \mathrm{p}<0.0001)$ computer, educational computer applications ( $\mathrm{rs}=0.817, \mathrm{p}<0.0001)$, electronic calculators ( $\mathrm{r}=0.937, \mathrm{p}<0.0001$ ), handheld computers ( $\mathrm{r}=0.755, \mathrm{p}<0.001)$, interactive boards ( $\mathrm{rs}=0.879, \mathrm{p}<0.001)$ and emails $(\mathrm{rs}=0.754, \mathrm{p}<0.001)$ in subject teaching.

It turned out that the pedagogues who are able to efficiently integrate ICTs in separate topics of a subject, most often use electronic calculators and video cameras ( $r s=0.655, p<0.0001)$. And vice versa, the better pedagogues evaluate their knowledge on basic provisions for the integration of ICT in the study subject and are able to use the available ICT learning environment in subject teaching, the less they use video cameras (respectively $r s=-0.937, p<0.0001$ and $r s=-0.931$, $\mathrm{p}<0.0001$ ). This suggests that the tools like electronic calculators and video cameras are not widely applied and could be used only in teaching separate topics of a subject. A similar tendency is observed also in evaluating other knowledge, abilities and attitudes of pedagogues.

According to the obtained results, the aims of ICT usage during lessons correlate with the pedagogues' competence. Four levels of pedagogues' ICT competence were analysed: 1 . Behavioural level of competence, i.e. elementary behaviour according to the requirements of a workplace; 2 . Additive level of competence, i.e. behaviour and knowledge interpreted as value added; 3. Integrative level of knowledge, i.e. knowledge integration via creative activity; 4. Holistic competence (Jucevičienè, 2005). The level of pedagogues' competence is a derived indicator obtained by calculating and transforming pedagogues' knowledge, abilities and skills.

According to the research, the more teachers consider themselves as competent pedagogues, the more convinced they are that ICT facilitates collaborative work of teachers and students ( $\mathrm{rs}=0.732, \mathrm{p}<0.0001)$. ICTs help to generate a pleasant atmosphere in the classroom ( $\mathrm{rs}=0.610, \mathrm{p}<0.0001)$, diversify the learning process and make learning more attractive $(\mathrm{r} s=0.496, \mathrm{p}<0.0001)$.

The research revealed that ICT opportunities during the learning process are related to the pedagogical work experience: usually teachers with extensive pedagogical work experience are among those who claim that the use of ICT impedes the learning process due to the poor computer provision in schools ( $\mathrm{rs}=0.523$, $\mathrm{p}<0.0001)$. In other words, the pedagogues having more extensive pedagogical work experience state that the better computer provision in school is the more possibilities they have to apply ICTs in the education process.

It was noted that the respondents with shorter pedagogical experience more positively evaluated ICT as a tool providing for more effective control of the education process ( $\mathrm{rs}=-0.732, \mathrm{p}<0.0001)$. This means that lack/absence of pedagogical experience prevents from an adequate evaluation of the situation. In conclusion, it 
could be said that pedagogues having no extensive pedagogical work experience use all ICT opportunities in organising the education process in general education schools, and usually apply ICTs as a control measure.

In order to analyse the experience of ICT usage in general education schools, it is necessary to identify factors having a major influence on the formation of pedagogues' attitudes. In view of this, regressive analysis was applied for data analysis. Regression analysis is a statistical process for estimating relationships among variables and anticipating the meanings of one variable according to changes in other variables. A multiple linear regression model was applied. Dependent variables determining ICT evaluations were selected (ICT facilitates collaborative work between teachers and students (promotes cooperation); use of ICT improves the atmosphere in the classroom (there is no competition among pupils, they feel safel protected and less distracted etc.); ICTs allow for better monitoring of the education process; the use of ICT diversifies the opportunities of learning and makes learning more attractive, as well as independent variables (pedagogues' work experience, qualification, subjects taught, ICT competence). Indicators of the suitability of the regression model are presented in Table 2.

Table 2. Assessment of suitability of the multiple regression model

\begin{tabular}{llllll}
\hline No $\quad$ Dependent variables: pedagogues' evaluation & $\mathbf{R}^{2}$ & $\mathbf{R}^{2}{ }_{\alpha}$ & ANOVA & $\begin{array}{c}\text { Durbin- } \\
\text { Watson } \\
(\mathbf{d})\end{array}$ \\
\hline 1. & $\begin{array}{l}\text { ICT facilitates collaborative work between teachers } \\
\text { and students (promotes cooperation) }\end{array}$ & 0.692 & 0.690 & $\mathrm{p}<0.000$ & $\mathrm{~d}=1.405$ \\
\hline $\begin{array}{l}\text { The use of ICT improves the atmosphere in the } \\
\text { classroom (there is no competition between stu- } \\
\text { dents, they feel safe/protected and less distracted } \\
\text { etc.) }\end{array}$ & 0.411 & 0.407 & $\mathrm{p}<0.000$ & $\mathrm{~d}=2.162$ \\
\hline $\begin{array}{l}\text { ICTs allow for better monitoring of the education } \\
\text { process }\end{array}$ & 0.463 & 0.460 & $\mathrm{p}<0.000$ & $\mathrm{~d}=2.090$ \\
\hline $\begin{array}{l}\text { The use of ICT diversifies the opportunities of } \\
\text { learning and makes learning more attractive }\end{array}$ & 0.359 & 0.355 & $\mathrm{p}<0.000$ & $\mathrm{~d}=1.405$ \\
\hline
\end{tabular}

$\mathrm{R}^{2}$ - determination coefficient indicating whether the model fits the observed data. A high value of the coefficient of determination means model adequacy (the required $\mathrm{R}^{2} \geq 0.25$. Durbin-Watson (d) criterion indicates that there is no autocorrelation in the model ( $\mathrm{d}$ statistics is close to 2 ).

Below there is an illustration of the statistical values of the dependent variable "ICT facilitates collaborative work between teachers and pupils" and independent 
variables "pedagogical work experience, pedagogue's qualifications, taught subject, pedagogue's ICT competence" by applying the method of multiple regression analysis (cf. Table 3).

Table 3. Multiple regression model. ICT evaluations: ICT facilitates collaborative work between teachers and pupils

\begin{tabular}{|c|c|c|c|c|c|c|c|c|}
\hline \multirow{2}{*}{$\begin{array}{c}\text { Dependent } \\
\text { variable } \\
\text { (Y1) }\end{array}$} & \multirow{2}{*}{$\begin{array}{l}\text { Independ- } \\
\text { ent vari- } \\
\text { ables }\end{array}$} & \multirow{2}{*}{$\begin{array}{l}\text { Con- } \\
\text { stant }\end{array}$} & \multicolumn{3}{|c|}{$\begin{array}{l}\text { Non-standardised coef- } \\
\text { ficients }\end{array}$} & \multicolumn{3}{|c|}{ Standardised coefficients } \\
\hline & & & b & $\mathrm{F}$ & $\begin{array}{c}\text { ANOVA } \\
\mathrm{p}\end{array}$ & $\beta$ & $\mathrm{t}$ & $p_{\text {H0:bj=0 }}^{p}$ \\
\hline \multirow{4}{*}{$\begin{array}{l}\text { ICT } \\
\text { facilitates } \\
\text { collabora- } \\
\text { tive work } \\
\text { between } \\
\text { teach- } \\
\text { ers and } \\
\text { students }\end{array}$} & $\begin{array}{l}\text { Pedagogi- } \\
\text { cal work } \\
\text { experience }\end{array}$ & \multirow{4}{*}{-0.813} & -0.044 & 337.435 & 0.0001 & -0.187 & -7.839 & 0.0001 \\
\hline & $\begin{array}{l}\text { Pedagogue's } \\
\text { qualifica- } \\
\text { tions }\end{array}$ & & -0.129 & 337.435 & 0.0001 & -0.311 & -13.457 & 0.0001 \\
\hline & $\begin{array}{l}\text { Subject } \\
\text { taught }\end{array}$ & & -0.035 & 337.435 & 0.0001 & -0.085 & -3.688 & 0.0001 \\
\hline & $\begin{array}{l}\text { Pedagogue's } \\
\text { ICT compe- } \\
\text { tence }\end{array}$ & & 0.785 & 337.435 & 0.0001 & 0.676 & 28.759 & 0.0001 \\
\hline
\end{tabular}

The values of the indicated $b$ coefficients are low but significant from the statistical point of view $(\mathrm{p}<0.001)$. The coefficients of pedagogical work experience, the pedagogue's qualifications and a subject taught are negative, therefore the increasing coefficient reduces the estimate of a dependent variable (ICT facilitates joint work of teachers and pupils) unless this decrease is outweighed by the coefficient of ICT competence. The pedagogue's qualifications have a negative impact on this dependent variable $(\beta=-0.311)$, whereas a positive result is determined by the pedagogue's increasing ICT competence $(\beta=0.676)$.

Such a logical construction of the data analysis is also applied to the analysis of other dependent variables (Table 4).

The provided standardised estimates of $\beta$ coefficient with respect to all the statements demonstrate that pedagogical work experience has a negative impact on pedagogues' evaluation regarding the following statements: ICT facilitates collaborative work between teachers and pupils $(\beta=-0.187)$; the use of ICT improves the atmosphere in the classroom $(\beta=-0.169)$; ICTs allow for better monitoring of the education process $(\beta=-0.341)$. According to the research, pedagogues' qualifica- 
Table 4. Multiple regression coefficient ( $\beta$ estimates) for pedagogues' evaluation

\begin{tabular}{|c|c|c|c|c|c|c|}
\hline No & $\begin{array}{l}\text { Dependent variables (Yi): } \\
\text { pedagogues' evaluation }\end{array}$ & $\begin{array}{l}\text { Con- } \\
\text { stant }\end{array}$ & $\begin{array}{c}\text { X1 } \\
\text { Pedagogues' } \\
\text { qualification }\end{array}$ & $\begin{array}{c}\mathrm{X} 2 \\
\text { Subject } \\
\text { taught }\end{array}$ & $\begin{array}{c}\mathrm{X} 3 \\
\begin{array}{c}\text { Pedagogical } \\
\text { work experience }\end{array}\end{array}$ & $\begin{array}{c}\mathrm{X} 4 \\
\text { Pedagogues' } \\
\text { ICT competence }\end{array}$ \\
\hline 1. & $\begin{array}{l}\text { ICT facilitates collaborative } \\
\text { work between teachers and } \\
\text { pupils (promotes cooperation) }\end{array}$ & -0.813 & $\begin{array}{c}-0.311 \\
\mathrm{p}=0.0001\end{array}$ & $\begin{array}{c}-0.085 \\
\mathrm{p}=0.0001\end{array}$ & $\begin{array}{c}-0.187 \\
\mathrm{p}=0.0001\end{array}$ & $\begin{array}{c}0.676 \\
p=0.0001\end{array}$ \\
\hline 2. & $\begin{array}{l}\text { The use of ICT improves the } \\
\text { atmosphere in the classroom } \\
\text { (there is no competition } \\
\text { between students, they feel safe/ } \\
\text { protected and less distracted } \\
\text { etc.) }\end{array}$ & -1.048 & $\begin{array}{c}-0.015 \\
p=0.630\end{array}$ & $\begin{array}{c}0.088 \\
\mathrm{p}=0.006\end{array}$ & $\begin{array}{c}-0.169 \\
\mathrm{p}=0.0001\end{array}$ & $\begin{array}{c}0.575 \\
\mathrm{p}=0.0001\end{array}$ \\
\hline 3. & $\begin{array}{l}\text { ICTs allow for better monitoring } \\
\text { of the education process }\end{array}$ & 0.138 & $\begin{array}{c}-0.306 \\
\mathrm{p}=0.0001\end{array}$ & $\begin{array}{c}0.007 \\
p=0.817\end{array}$ & $\begin{array}{c}-0.341 \\
\mathrm{p}=0.0001\end{array}$ & $\begin{array}{c}0.393 \\
p=0.0001\end{array}$ \\
\hline 4. & $\begin{array}{l}\text { The use of ICT diversifies the } \\
\text { opportunities of learning and } \\
\text { makes learning more attractive }\end{array}$ & -0.187 & $\begin{array}{c}0.448 \\
\mathrm{p}=0.0001\end{array}$ & $\begin{array}{c}0.123 \\
p=0.0001\end{array}$ & $\begin{array}{c}0.269 \\
p=0.0001\end{array}$ & $\begin{array}{c}0.267 \\
p=0.0001\end{array}$ \\
\hline
\end{tabular}

tions $(\beta=0.448)$ have a positive impact on pedagogues' evaluation (The use of ICT diversifies the opportunities of learning and makes learning more attractive).

A regression equation was determined by using the non-standardised coefficient estimates (b) allowing for identifying which variables have major weight in forming pedagogues' views on the use of ICT during the learning process. Below there is the equation of the fourth dependent variable the use of ICT diversifies the opportunities of learning and makes learning more attractive.

$\mathrm{Y}=-0.187+0.448 \cdot \mathrm{x}_{1}+0.123 \cdot \mathrm{x}_{2}+0.269 \cdot \mathrm{x}_{3}+0.267 \cdot \mathrm{x}_{4}$

It was noted that pedagogues' qualifications have a major impact on the formation of pedagogues' attitudes $(\beta=0.448)$.

In applying the dispersion analysis (ANOVA) major differences were determined between the pedagogues of different subjects (mathematics, physics, etc.) and time allocated for ICT integration $(F=1.668 ; p=0.173)$. In view of this, the analysis was pursued by applying the Scheffe criterion $(\mathrm{p}<0.01)$. It was established that statistically the major difference was in the time allocated by the teachers of biology and mathematics in integrating ICT tools in teaching subjects during the recent three months. On average the teachers of mathematics allocated about $50 \%$ of their time for the integration of ICT tools (teachers of biology - about 30\%). 


\section{Conclusions}

1. The aims of ICT usage during lessons precisely correlate with pedagogues' ICT competence. The teachers mastering ICT skills realise that ICT usage for educational reasons has a positive impact on education and can increase the effectiveness of the process; this determines diversity of ICT usage goals.

2. Pedagogues' work experience correlates with the ICT usage during the teaching/learning process: the pedagogues with longer work experience have more experience in ICT usage and see more possibilities for ICT usage in the teaching/learning process. The teachers having short pedagogical work experience relate the use of ICT during lessons to the improvement of organisational lesson elements (atmosphere, control).

3. Pedagogues' opinion about the use of ICT during the learning process is mainly determined by their qualifications, work experience and ICT competence.

\section{References}

A Framework to Support Teachers' CPD in the use of ICTs. Public Progress Report (2007) Retrieved 21/02/2014, from http://eacea.ec.europa.eu/llp/projects/public_parts/documents/ict/pr_ict_etq.pdf

Anderson, J. \& van Weert, T. (Eds) (2002). Information and Communication Technology in Education: A Curriculum for Schools and Programme of Teacher Development. Paris: UNESCO. Retrieved 25/08/2014, from http://unesdoc.unesco.org/ images/0012/001295/129538e.pdf

Bingimlas, K., A. (2009) Barriers to the Successful Integration of ICT in Teaching and Learning Environments: a Review of the Literature. Eurasia Journal of Mathematics, Science and Technology Education. 5(3), 235-245.

Bitinas, B. (2006). Educational research: the system and process. Vilnius: Kronta.

Brazdeikis, V. (2010) Integration of Education Information Systems. E-Education: science, study and business: conference proceedings. Kaunas: Technologija. Retrieved 21/02/2014, from http://www.lvu.lt/cms/files/liedm/resources/3931_e_svietimas_pranesimu_medziaga.pdf

Brazdeikis, V., Masaitis, M. (2011) Computer educational means in education environments. XV Conference papers on computer science. 33-45. Retrieved 21/02/2014, from http:// eia.libis.lt/viesas/Leidiniai/XV_kompiuterininku_konferencijos_mokslo_darbai/ KODI2011-md-2-leidimas.pdf

Dagienė, V., Jasutienè, E. (2007). Information technologies for visualization and exploration of math. Information Sciences, 76-88. 
E-Teacher 2.0 Empowering Teacher's ICT-Pedagogical Competencies. (2010) European Commission-funded project. LLP-LdV-ToI-2010/DK-1010. Retrieved 17/09/2014, from www.adam-europe.eu/prj/6574/project_6574_en.pdf

Gedvilienè, G., Laužackas, R., Tūtlys, V. (2010). Teacher in-service training needs. Scientific study. Kaunas: Vytautas Magnus University.

Gudonienè, D. (2011) Application of new ICT methods in Lithuania schools. XV Conference papers on computer science. 86-97. Retrieved 21/02/2014, from http://eia.libis.lt/ viesas/Leidiniai/XV_kompiuterininku_konferencijos_mokslo_darbai/KODI2011-md2-leidimas.pdf

Indrašienė, V., Penkauskienè, D., Suboč, V., Matonytė, A. (2010). Integration of critical thinking principles into Lithuanian education system. Retrieved 20/12/2014, from: http://www. sdcentras.lt/pr_ctp/tyrimas.pdf

Information technologies in XXI century schools (2012). Analysis of the problem of education Nr. 7 (47).

Jucevičienè, P. (2005). Teacher training in the aspect of development of ICT: case of Lithuania. Scientific study. Retrieved 15/01/2014, from http://www.itc.smm.lt/wp-content/ uploads/2009/11/Pedagogu-rengimo-IKT-diegimo-Lietuvos-svietime-asp.pdf

Jucevičienè,P., Brazdeikis V. (2012) The effectiveness of ICT competence evaluation strategies. Research papers. Societal Innovation for Global Growth vol. 1, 367-375. Retrieved 01/08/2015, from: http://socin.mruni.eu/wp-content/uploads/2012/12/B_2012-12-26.pdf

Jucevičienè. P. (2013). Approach to education - conceptual basis on relationship between educational and learning environment // Leonas Jovaiša: from pedagogy toward educational science: scientific study. Vilnius: Vilnius University press.

Key Data on Learning and Innovation through ICT at School in Europe (2011). EU Commission document. Retrieved 12/06/2014, from http://eacea.ec.europa.eu/education/ eurydice/documents/key data series/129EN.pdf

Kuskaya-Mumcu, F., Koçak-Usluel, Y., (2013) Teachers' Perceptions Related to Levels of ICT Implementation. Procedia - Social and Behavioral Sciences, 83, 729-733.

Professional development of Lithuanian teachers' (2010). Retrieved 11/08/2014, from http:// www.smm.lt/svietimo_bukle/docs/pr_analize/sv_problema_5.pdf

Lukšènienè, A., Žygaitienè, B., Pošiūnaitè, K. (2014) ICT measures application of peculiarities in technology lessons. Pedagogy, 113, Nr. 1, 148-158.

Means, B., (2010). Technology and Education Change: Focus on Student Learning. Journal of Research on Technology in Education. 42(3). 285-307. Retrieved 15/01/2015, from http://www.sri.com/work/publications/technology-and-education-change-focusstudent-learning.

Information and Communication Technologies (ICT) in education. Schools research. Case of Lithuania (2012). Retrieved 21/02/2014, from http://www.draugiskasinternetas. lt/repository/dokumentai/ataskaitos/MOKYKLU_TYRIMAS_IKT_svietime_Informacija_apie_Lietuva_2012.pdf

Pečiuliauskienè, P. (2010). Educational innovations in comprehensive schools: teachersinnovators attitude to the factors. Pedagogy, 100, 57-63. 
Prell, (2011) Social Network Analysis: History, Theory and Methodology. SA GE Publications.

Pukenas, P. (2011). Qualitative data analysis using SPSS program. Kaunas: LKKA.

Punie, Y., Zinnbauer, D., \& Cabrera, M. (2006). A review of the Impact of ICT on Learning. Working paper prepared for DG EAC. Institute for Prospective Technological Studies (IPTS), JRC, European Commission. Retrieved 20/12/2014, from http://ipts.jrc. ec.europa.eu/publications/pub.cfm?id=1746

Ross, S.M. \& Lowther, D.L. (2009) Efeectively using technology in education. Better Evidence-Based Education, 2(1), 20-21.

Survey of Schools: ICT in Education: Benchmarking Access, Use and Attitudes to Technology in Europe's Schools (2013). Retrieved 21/02/2014, from https://ec.europa.eu/digitalagenda/sites/digital-agenda/files/KK-31-13-401-EN-N.pdf

Teaching and learning for an ICT revolutionised society. (2010). European Commission, European Research Area. Retrieved 17/06/2014, from http://www.foresight-platform. eu/wp-content/uploads/2011/04/EFP-Brief-No.-178_ICT-in-Education.pdf

The ICT Impact Report A review of studies of ICT impact on schools in Europe. (2006). European Commission, UNESCO 2008b. ICT Competency Standards for Teachers: Competency Standard Modules. Retrieved 17/06/2014, from http://unesdoc.unesco. org/images/0015/001562/156207e.pdf

Unesco ICT competency framework for teachers, (2011). Retrieved 20/10/2014, from http:// unesdoc.unesco.org/images/0021/002134/213475e.pdf

Vaitkevičius, R., Saudargiene, A. (2006). Statistics with SPSS in psychological research. Kaunas: VDU press.

Žadeikaité, L., Gulbinas, R. (2014). Social educators' accessibility, significance and usage of educational environment enriched with ICT tools. Learners and Educators competence change, (37)1, 134-145. 